УДК 576.5:611.37

(C) 2016

Ковпак В. В., кандидат ветеринарних наук, докторант

(науковий консультант - доктор ветеринарних наук А. Й. Мазуркевич)

Національний університет біоресурсів і природокористування України

\title{
ФЕНОТИПОВІ ТА МОРФОЛОГІЧНІ ЗМІНИ В КУЛЬТУРІ КЛІТИН ПІДШЛУНКОВОЇ ЗАЛОЗИ ЩУРІВ ПІД ЧАС КУЛЬТИВУВАННЯ
}

\section{Рецензент - доктор ветеринарних наук, професор В. І. Карповський}

Дослідження морфології первинної культури клітин підилункової залози показало, щчо вона морфологічно гетерогенна, серед домінуючих фібробластоподібних клітин відмічали незначну кількість полігональних. 3 другого пасажу культура ставала гомогенною за рахунок фібробластоподібних клітин. Методом імунофенотипування популяиї культури клітин, отриманих з підшлункової залози щура, було виявлено високий рівень експресії маркера CD38; помірний рівень - CD66е, CD95, CD326; низький рівень - CD227; відсутність експресї-CD10, CD34, CD45, CD48, CD54, CD56, nанкератину.

Ключові слова: культура клітин, підшлункова залоза, імунофенотипування, морфологія клітин.

Постановка проблеми. Цукровий діабет I типу (ЦД1) є одним із найбільш поширених серед аутоімунних захворювань [11]. Картина патогенезу ЦД І типу, яка істотно доповнена за останні роки, свідчить про активну участь імунних механізмів у порушенні ендокринної функції панкреатичних острівців, що призводить до знищення інсулін-продукуючих клітин в панкреатичних острівцях Лангерганса $[11,3]$.

На даний час лікування цукрового діабету I типу не передбачає повного видужування. Розглядається виключно досягнення максимально можливої компенсації вуглеводного обміну, запобігання гіпо- та гіперглікемії і профілактики, таким чином, ускладнень цукрового діабету. Тобто призначення замісної терапії (препаратів інсуліну) є довічним [5].

Аналіз основних досліджень і публікацій, у яких започатковано розв'язання проблеми. Клітинна терапія - давно не новий метод у лікуванні цукрового діабету, а одним із найперспективніших кандидатів у якості трансплантату $є$ культура клітин підшлункової залози [16, 21]. Однак практичне впровадження клітинної терапії вимагає кропіткого експертного аналізу вихідного матеріалу, ретельної деталізації кожного 3 етапів застосування клітин, відстеження подальшої долі останніх in vitro та in vivo [1]. Виникають питання, зокрема щодо класифікації клітин залежно від способу їх отримання та ступеня зрілості. 3 огляду на останнє, фенотипування культури клітин підшлункової залози є актуальним та своєчасним.

Мета дослідження - дослідити морфологічні та фенотипові зміни клітин підшлункової залози в процесі їх культивування in vitro 3 першого до четвертого пасажу.

Завдання: отримати культуру клітин підшлункової залози, прослідкувати морфологічні та фенотипові зміни в отриманій культурі в процесі культивування та проаналізувати отримані результати.

Матеріали і методи досліджень. Експерименти на тваринах були проведені з дотриманням вимог Закону України «Про захист тварин від жорстокого поводження» (ст. 230 від 2006 року), «Загальних етичних принципів експериментів над тваринами», схвалених Національним конгресом 3 біоетики i узгоджених 3 положеннями «Свропейської конвенції щодо захисту хребетних тварин, яких використовують в експериментах та інших наукових цілях» (Страсбург, 1986). У досліді використали 9 нелінійних щуренят 12-денного віку.

Культуру клітин підшлункової залози (ККПЗ) отримували із залозистої частини підшлункової залози щурів. Для цього після евтаназії дослідних тварин, шляхом декапітації під ефірним наркозом, з черевної порожнини діставали підшлункову залозу та поміщали в стерильну чашку Петpi. Декілька разів ऑii промивали фосфатнобуферним розчином (PBS) («Sigma», США). Далі залозисту частину підшлункової залози відділяли від сполучної тканини та подрібнювали ножицями на шматочки $\approx 1 \mathrm{mм}^{3}$. Первинну культуру отримували методом експланту [14] 3 розрахунку 10-15 шматочків на чашку $(\mathrm{d}=3$ см) (рис. 1). Культивування здійснювали у стандартному середовищі: 80 \% - середовище Ігла модифіковане Дульбекко (DMEM); 20 \% - фетальна сироватка

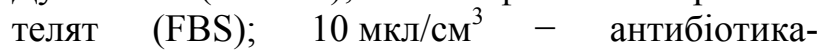
антимікотика («Sigma», США). 


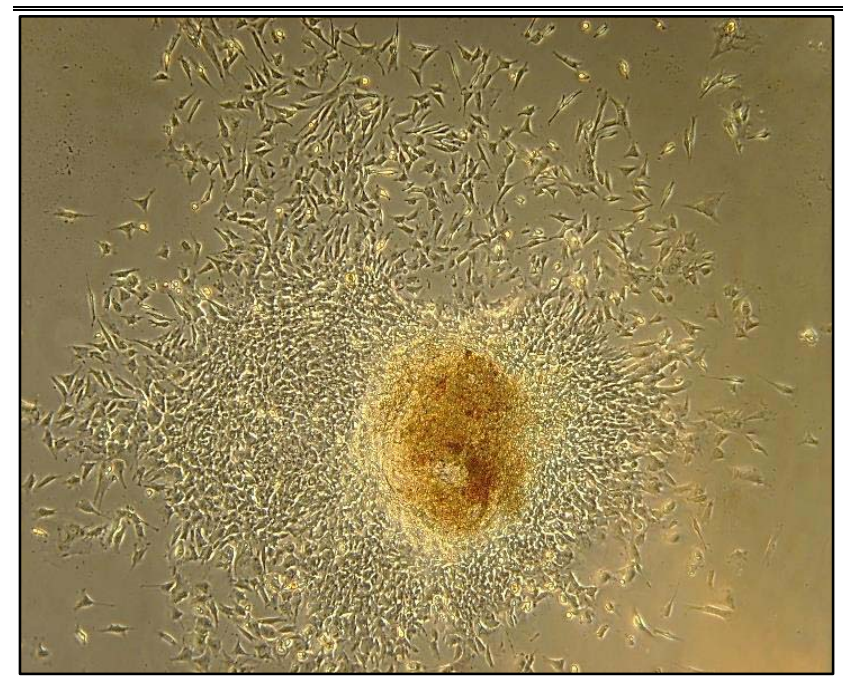

Рис. 1. Мікрофотографія первинного експланту підшлункової залози із розростанням клітин, 7-ма доба культивування in vitro. Нативний препарат. ок. $\times 10$, об. $\times 5$

Культивування проводили у $\mathrm{CO}_{2}$ інкубаторі за $37^{\circ} \mathrm{C}$ та $5 \%$ концентрації $\mathrm{CO}_{2} 14$ днів, до конфлюентності 90-100\%.

Клітини знімали за стандартною методикою (розчином 0,25\% трипсин/ЕДТА) [4]. Подальше пасажування здійснювалось у розведенні 1:3. Мікроскопічний аналіз і оцінку культури здійснювали за допомогою інвертованого мікроскопа Axiovert 40 (Карл Цейс).

Контроль зміни фенотипу проводили шляхом виявлення CD-маркерів (CD10, CD38, CD34, CD45, CD48, CD54, CD56, CD66e, CD96, CD227, CD326, пан-кератин). Для цього клітини вирощували на покривних скельцях. Скельця з клітинами промивали тричі у PBS, після чого фіксували розчином метанол/оцтова кислота (1:1) («Sigma», США), t $-4{ }^{0} \mathrm{C}$ протягом 2-х годин. Далі промивали тричі у PBS. Скельця переносили на 20 хвилин у $1 \%$ розчин бичачого сироваткового альбуміну на PBS. Потім скельця струшували від рідини та наносили первинні антитіла (розведення 1:100), експозиція 1 година. Після чого скельця промивали двічі у PBS та наносили вторинні антитіла AlexaFluor 488 donkey anti-mouse IgG $(\mathrm{H}+\mathrm{L})$ (розведення 1:500) («Invitrogen», США), експозиція 1 година. Далі скельця промивали тричі у PBS, на скельця наносили гліцерин та закріплювали на них покривні скельця [4].

Дослідження зразків здійснювали за допомогою флуоресцентного мікроскопа Leica DMR (Німеччина).

Оцінку проводили напівкількісно (метод $\mathrm{H}$ Score), були обрані 20 полів у випадковому порядку в разі збільшення х400. Середній бал вирахову-

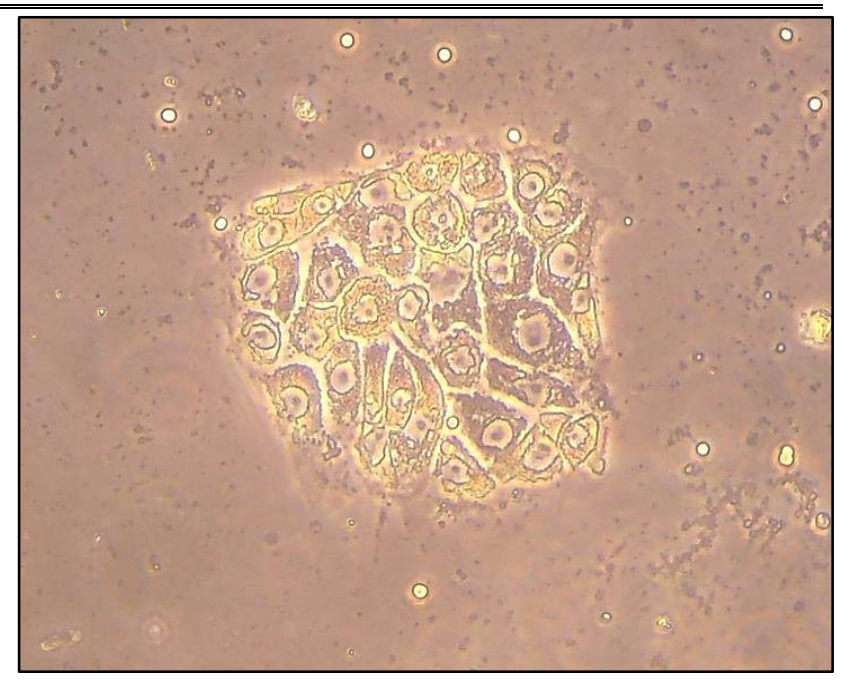

Рис. 2. Мікрофотографія колонії полігональних клітин, отриманої з підилункової залози, 7-ма доба культивування in vitro. Нативний препарат. ок. $\times 10$, об. $\times 32$

вали за формулою: $\mathrm{S}=1 \mathrm{xA}+2 \mathrm{xB}+3 \mathrm{xC}$, де $\mathrm{S}-$ показник «H-Score», значення якого знаходяться у межах від 0 (білок не експресується) до 300 (сильна експресія у 100 \% клітин); А - клітини зі слабкою експресією; В - відсоток клітин з помірною експресією білка; С - відсоток клітин із сильною експресією. Ступінь експресії визначали як негативний, якщо число балів було в діапазоні від 0 до 50; низький - від 51 до 100; помірний - від 101 до 200; високий - 201 і вище [6].

Результати досліджень. Морфологічна характеристика культури клітин підилункової залози. Первинна культура клітин підшлункової залози щурів характеризувалася морфологічною гетерогенністю.

Починаючи з 2-го дня культивування, ми спостерігали розростання клітин фібробластоподібної морфології навколо прикріпленого до культурального пластику експланту (рис. 1).

На 5-й день нами було відмічено утворення поодиноких колоній, які складалися 3 клітин полігональної форми (рис. 2).

Починаючи 3 10-го дня, відмічали початок злиття колоній різної морфології (рис. 3).

Проте варто зазначити, що клітини фібробластоподібної морфології відзначалися більшою швидкістю поділу, у порівнянні з полігональними клітинами, на момент досягнення конфлюентності $90 \%$ їх кількість становила приблизно $80 \%$ від клітинної маси первинної культури підшлункової залози.

Первинна ККПЗ досягала конфлюентності 90$100 \%$ у середньому за 14 днів. 


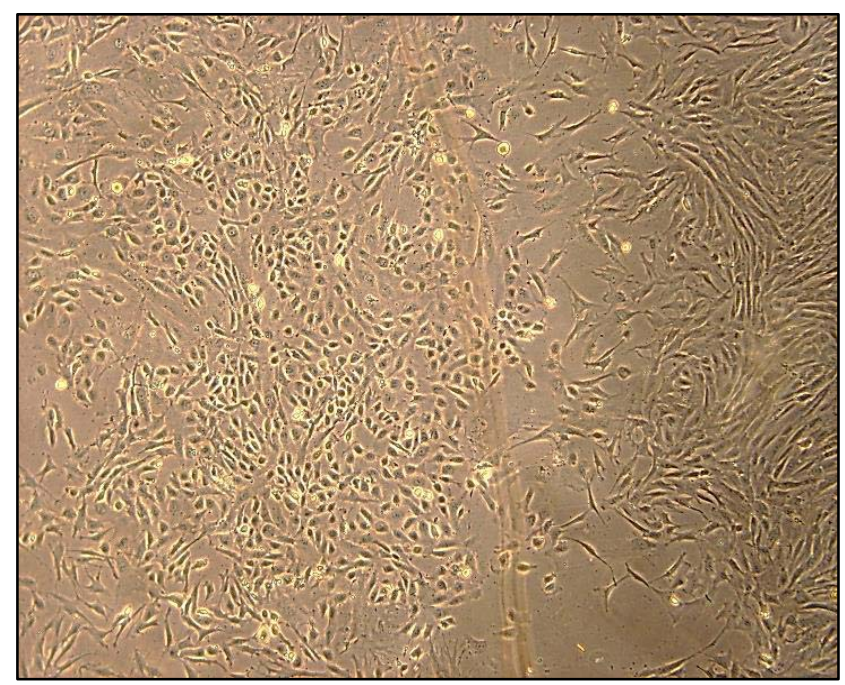

Рис. 3. Мікрофотографія злиття колоній різної морфології первинної культури клітин підшлункової залози, 10-та доба культивування (0 пасаж) in vitro.

Нативний препарат. ок. $\times 10$, об $\times 5$

На першому пасажі продовжували відмічати гетерогенність культури, ККПЗ щурів складалася 3 поодиноких клітин полігональної форми, оточених фібробластоподібними клітинами (рис. 4). Починаючи 3 другого пасажу, культура ставала гомогенною за рахунок фібробластоподібних клітин.

Характеристика культури клітин підилункової залози за поверхневими маркерами. Імунофенотипування популяції культури клітин, отриманих із підшлункової залози щура, дало змогу виявити високий рівень експресії маркера $\mathrm{CD} 38$; помірний рівень - CD66e, CD95, CD326; низький рівень - CD227; відсутність експресії - CD10, CD34, CD45, CD48, CD54, CD56, пан-кератину (див. табл.).

$\mathrm{CD} 38$ - одноланцюговий трансмембранний глюкопротеїд II типу. Даний маркер використовують для типування лімфоцитів і часто розглядають як лімфоцит-специфічний антиген [7, 22], проте пізніше було виявлено, що даний маркер експресується практично у всіх тканинах $[23,12]$. CD 38 регулює низку клітинних функцій, зокрема хемотаксис [19], клітинну проліферацію [26, 10], секрецію інсуліну [18] та багато інших. Під час дослідження нами було відмічено достовірне збільшення експресії даного маркера 396 (I пасаж) до 261 балів (IV пасаж). Проте через широкий спектр функціональності CD 38 не можливо дати однозначної відповіді про причину збільшення його експресії під час культивування.

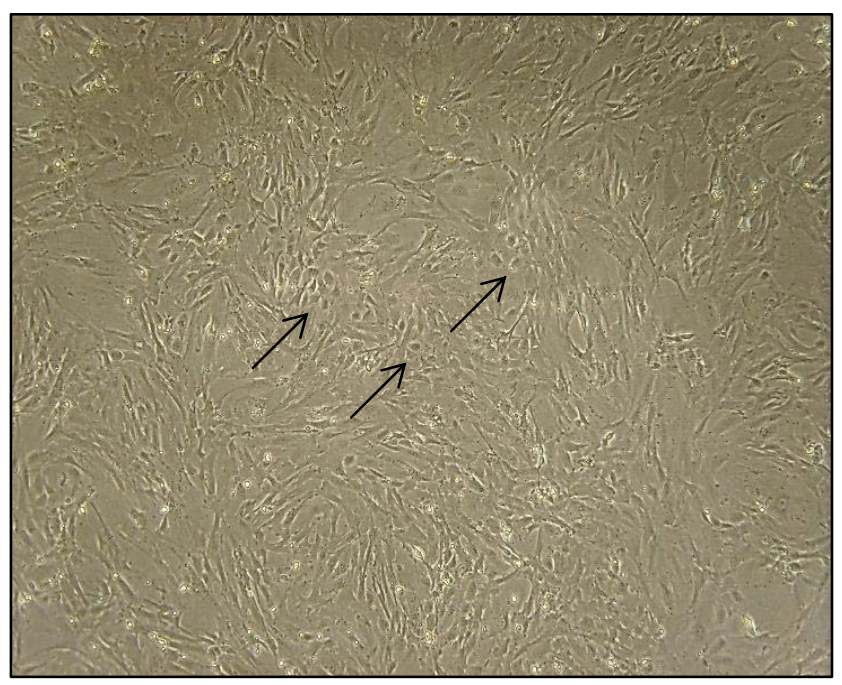

\section{Рис. 4. Мікрофотографія моношару ККПЗ (стрілками вказані поодинокі округлі клітини), 1 пасаж. \\ Нативний препарат. ок. $\times 10$, об $\times 5$}

CD66e - глікозольований глюкопротеїд поверхневої мембрани епітеліальних клітин [13]. Маркер клітинної адгезії [25], клітинної міграції збуджує зв'язування та активацію сигнальних шляхів [9], експресується епітеліальними клітинами, чим пояснюється виявлення CD66e у більшості органів [13]. Нормальні клітини зазвичай піддаються апоптозу за відсутності адгезивних взаємодій 3 CD66e - явище відоме як «аноікіс» («anoikis»). Стійкість до аноікісу характерна для пухлинних клітин [9]. CD66e у досліджуваній культурі клітин достовірно збільшується 3 першого (11 балів) до четвертого (112 балів) пасажу. Отримані дані можуть вказувати на відсутність активної неопластичної трансформації ККПЗ.

CD95 - трансмембранний глюкопротеїд I типу опосередковує сигнал, що ініціює апоптоз [24]. Починаючи 3 першого пасажу, інтенсивність експресії даного маркера достовірно збільшується від 102 до 174 балів відповідно. Дані росту експресії CD95 корелюють з рівнем апоптозу у культурі клітин, що було досліджено нами раніше [2]. Отже, з отриманих даних можна зробити висновок, що підвищення рівня CD95 пояснюється збільшенням клітин у стані апоптозу.

CD227 - трансмембранний глікопротеїн, що експресується епітеліальними клітинами та виконує функцію захисту від бактерій та ферментів [2]. Під час дослідження нами відмічалося збільшення експресії CD227 з першого (57 балів) до четвертого (94 бали) пасажу. 
ВЕТЕРИНАРНА МЕДИЦИНА

Зміна експресії поверхневих маркерів у популяції клітин підилункової залози шура з першого до четвертого пасажу $(M \pm m, n=3)$

\begin{tabular}{|c|c|c|c|c|}
\hline \multirow{2}{*}{$\begin{array}{c}\text { Поверхневі } \\
\text { маркери }\end{array}$} & \multicolumn{4}{|c|}{ Пасаж } \\
\cline { 2 - 5 } & I & II & III & IV \\
\cline { 2 - 5 } & \multicolumn{3}{|c|}{ Оцінка в балах за методом H-Score (від 0 до 300) } \\
\hline 10 & $0 \pm 0,0$ & $0 \pm 0,0$ & $0 \pm 0,0$ & $0 \pm 0,0$ \\
\hline 34 & $0 \pm 0,0$ & $18 \pm 5^{*}$ & $29 \pm 8^{*}$ & $38 \pm 11^{* *}$ \\
\hline 38 & $96 \pm 14$ & $170 \pm 11^{*}$ & $206 \pm 17^{* *}$ & $261 \pm 13^{* *}$ \\
\hline 45 & $0 \pm 0,0$ & $0 \pm 0,0$ & $0 \pm 0,0$ & $13 \pm 6$ \\
\hline 48 & $0 \pm 0,0$ & $0 \pm 0,0$ & $0 \pm 0,0$ & $0 \pm 0,0$ \\
\hline 54 & $0 \pm 0,0$ & $0 \pm 0,0$ & $0 \pm 0,0$ & $7 \pm 4$ \\
\hline 56 & $0 \pm 0,0$ & $0 \pm 0,0$ & $0 \pm 0,0$ & $112 \pm 21^{* *}$ \\
\hline 66 e & $11 \pm 3$ & $62 \pm 21$ & $75 \pm 14^{*}$ & $174 \pm 15^{*}$ \\
\hline 95 & $102 \pm 21$ & $127 \pm 17$ & $143 \pm 16$ & $94 \pm 9^{*}$ \\
\hline 227 & $57 \pm 9$ & $74 \pm 8$ & $90 \pm 6^{*}$ & $101 \pm 13^{*}$ \\
\hline 326 & $34 \pm 9$ & $42 \pm 9$ & $70 \pm 15$ & $0 \pm 0,0$ \\
\hline Пан-кератин & $0 \pm 0,0$ & $0 \pm 0,0$ & $0 \pm 0,0$ & \\
\hline
\end{tabular}

Примітка: * - $\mathrm{P}<0,05 ; * *$ - $\mathrm{P}<0,01 ; * * *$ - $\mathrm{P}<0,001$ порівняно $з$ контролем (контролем для кожного CD маркера виступав перший пасаж).

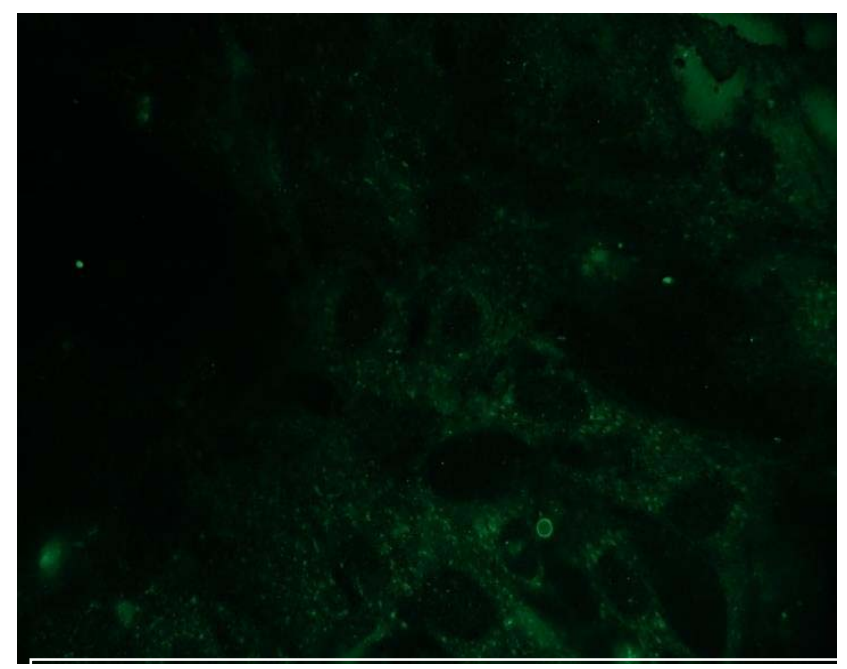

Pис. 5. Рівень експресії CD326 у культурі пidилункової залози, 1 пасаж. Флуоресцентна мікроскопія. 3б. $\times 2000$

CD326 - трансмембранний глікопротеїн першого типу - маркер епітеліальних клітин, який поєднує адгезивні та активаційні властивості, опосередковує ріст та диференціювання клітин $[17,26]$. Під час культивування нами відмічалось достовірне збільшення експресії CD326 від 34 до 101 балів з першого до четвертого пасажу відповідно (рис. 5, 6).

Експресію CD10, CD34, CD45, CD48, CD54, CD56 та пан-кератин упродовж усього терміну дослідження відносили до категорії «відсутність експресії».

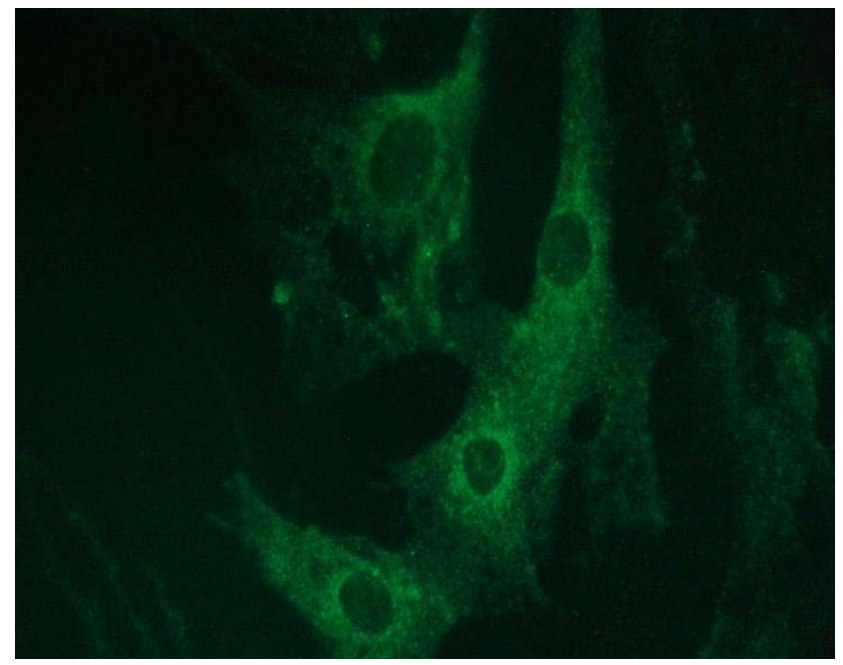

Puc. 6. Рівень експресії CD326 у культурі пidилункової залози, 4 пасажс. Флуоресцентна мікроскопія. 3б.×2000

Дослідження культури клітин підшлункової залози показало достовірне збільшення експресії маркерів характерних для епітеліальних клітин (CD66e, CD227, CD326) з першого до четвертого пасажу та набуття гомогенної структури, починаючи 3 другого пасажу за рахунок клітин фібробластоподібної морфології.

Клітини полігональної форми за рахунок низького рівня проліферації знижували свій відсотковий вміст у культурі, починаючи 3 нульового (максимальна кількість) до першого пасажу (поодинокі клітини у моношарі). 


\section{ВЕТЕРИНАРНА МЕДИЦИНА}

Також клітини полігональної форми могли піддаватися апоптозу, який збільшувався 3 пасажами (підтверджується збільшенням рівня CD95).

\section{Висновки:}

1. Первинна культура підшлункової залози щура характеризується гетерогенністю, відмічали невелику кількість клітин полігональної форми, оточених фібробластоподібними клітинами.

\section{БІБЛІОГРАФІЯ:}

1. Применение мезенхимальных стволовых клеток для восстановления структуры и функции поврежденных тканей и органов / [Бродский И. Б., Брянцева С. А., Жаппарова О. Н. и др.] // Эфферент. и физ.-хим. мед. - 2011. - №1. - С. 4-10.

2. Ковпак B. В. Цитогенетичний аналіз культури клітин підшлункової залози щурів на ранніх пасажах / В. В. Ковпак, О. С. Ковпак // Клітинна та органна трансплантологія. - 2016. №1, том 4. - С. 62-65.

3. Коновалова О. О. Ремоделювання жирової тканини при експериментальному цукровому діабеті / О. О. Коновалова, О.М.Камишний // Запорізький медичний журнал, 2013. - №4 (79). C. 95-98.

4. Мазуркевич А. Й. Клітинні технології у ветеринарній медицині : навчальний посібник / А. Й. Мазуркевич, В. В. Ковпак, В. Б. Данілов. К. : КОМПРИНТ, 2014. - 132 с.

5. Соколова И. Б. Клеточная терапия сахарного диабета I типа / И. Б. Соколова // Цитология. 2009. - №12, том 51. - С. 964-970.

6. Упоров A. B. Иммуногистохимическое изучение клеток рака молочной железы с использованием разных маркеров пролиферации / А. В. Упоров, В. Ф. Семиглазов, К. М. Пожарисский // Арх. патологии, 2000. - №2. - С. 26-30.

7. CD38 molecule: structural and biochemical analysis on human T lymphocytes, thymocytes, and plasma cells / [Alessio M., Roggero S., Funaro A. et al] // Immunol, 1990. - Vol. 3. P. 878-884.

8. The structural analysis of adhesions mediated by Ep-CAM / [Balzar M., Prins F. A., Bakker H. A. et al] // J. Mol. Med., 1999. - №10, Vol. 77. P. 699-712.

9. Blumenthal R. D. Inhibition of adhesion, invasion, and metastasis by antibodies targeting CEACAM6 (NCA-90) and CEACAM5 (CarcinoembryonicAntigen) / R. D. Blumenthal, H. J. Hansen, D. M. Goldenberg // Cancer. Res., 2005. - №19, Vol. 65. - P. 8809-8817.

10. Cyclic ADP-ribose is a second messenger in
2. У процесі культивування культура клітин стає більш гомогенною за рахунок фібробластоподібних клітин.

3. Протягом культивування відмічали достовірне збільшення поверхневих маркерів: CD38, CD66e, CD95, CD227, CD326.

4. Експресію CD10, CD34, CD45, CD48, CD54, CD56 та пан-кератин упродовж усього терміну дослідження відносили до категорії «відсутність експресії».

the lipopolysaccharide-stimulated proliferation of human peripheral blood mononuclear cells / [Bruzzone S., De Flora A., Usai C., Graeff R., Lee H. C.] // Biochem J. - 2003. - №375. - P. 395-403.

11. Culina $S$. Insulin and type 1 diabetes: immune connections / S. Culina, V. Brezar, R. Mallone // European Journal of Endocrinology, 2013. - №168. P. 19-21.

12. Analysis of the distribution of human CD38 and of its ligand CD31 in normal tissues / [Fernàndez J. E., Deaglio S., Donati D. et al] // J. Biol. Regul. Homeostatic Agents, 1998. - №12. P. 81-91.

13. Hammarström $S$. The carcinoembryonic antigen (CEA) family: structures, suggested functions and expression in normal and malignant tissues / S. Hammarström // Semin. Cancer. Biol., 1999. Vol. 9. - P. 67-81.

14. Ian R. Freshney Culture of animal cells: a manual of basic technique / Ian R. Freshney. $-\left[5^{\text {th }}\right.$ ed.]. - USA : John Wiley \& Sons, 2005. - 642 p.

15. Clinicopathology of sialomucin: MUC1, particularly KL-6 mucin, in gastrointestinal, hepatic and pancreatic cancers / [Inagaki Y., Xu H., Nakata M. et al] // Biosci. Trends, 2009. - №6. - P. 220-232.

16. Effect of transplantation site on the results of pancreatic islet isografts in diabetic rats / [Kemp C., Knight M., Scharp D. et al] // Diabetologia. - №9. P. 486-491.

17. The carcinoma-associated antigen EpCAM upregulates c-myc and induces cell proliferation / [Münz M., Kieu C., Mack B., Schmitt B. et al] // Oncogene, 2004. - №24, Vol. 23. - P. 5748-5758.

18. Okamoto $H$. Recent advances in the Okamoto Model: The CD38-Cyclic ADP-ribose signal system and the regenerating gene protein (Reg)-Reg receptor system in $\beta$-Cells / H. Okamoto, S. Takasawa // Diabetes. - 2002. - №51. - P. 462-473.

19. Cyclic ADP-ribose production by CD38 regulates intracellular calcium release, extracellular calcium influx and chemotaxis in neutrophils and is required for bacterial clearance in vivo / [PartidaSánchez S., Cockayne D. A., Monard S. et al] // Na- 


\section{ВЕТЕРИНАРНА МЕДИЦИНА}

ture Med., 2001. - №7. - P. 1209-1216.

20. Raina D. The MUC1 oncoprotein activates the anti-apoptotic phosphoinositide 3-kinase : Akt and Bcl-xL pathways in rat $3 \mathrm{Y} 1$ fibroblasts / D. Raina, S. Kharbanda, D. Kufe // Biol. Chem. 2004. - №20, Vol. 279. - P. 20607-20612.

21. Reckard C. Transplantation of isolated pancreatic islets across strong and weak histocompatibility barriers / C. Reckard, C. Barket // Transplant. Proc., 1973. - №5. - P. 761-763.

22. Discrete stages of human intrathymic differentiation: analysis of normal thymocytes and leukemic lymphoblasts of T-cell lineage / [Reinherz E. L., Kung P. C., Goldstein G. et al] // Proc. Natl. Acad. Sci., 1980. - №77. - P. 1588-1592.

23. Synthesis and hydrolysis of cyclic ADPribose by human leukocyte antigen CD38 and inhibition of the hydrolysis by ATP / [Takasawa S.,
Tohgo A., Noguchi N. et al] // J. Biol. Chem.1993. - №268. - P. 26052-26054.

24. Yonehara S. A cell-killing monoclonal antibody (anti-Fas) to a cell surface antigen co-down regulated with the receptor of tumornecrosis factor / S. Yonehara, A. Ishii, M. Yonehara // Exp. Med. 1989. - №5, Vol. 169. - P. 1747-1756.

25 . Tissue specific cytotoxicity of colon cancer cells mediated by nanoparticle-delivered suicide gene in vitro and in vivo / [Zhang G., Liu T., Chen Y. H., Chen Y. et al] // Clin Cancer Res. 2009. - №1, Vol. 15. - P. 201-207.

26. Stroma-generated cyclic ADP-ribose stimulates the expansion of early human hemopoietic progenitors by a paracrine interaction / [Zocchi E., Podestà M., Pitto A. et al] // FASEB J. - 2001. Express article 10.1096/fj.00-0803fje. 